\title{
Invisible Experts: A Systematic Review \& Thematic Synthesis of Informal Carer Experiences of Inpatient Mental Health Care
}

\author{
Nada Abou Sief \\ University College London \\ Lisa Wood ( l.wood@ucl.ac.uk) \\ University College London \\ Nicola Morant \\ University College London
}

\section{Research Article}

Keywords: Carers, family, inpatient, mental health, thematic analysis, qualitative

Posted Date: August 30th, 2021

DOI: https://doi.org/10.21203/rs.3.rs-647106/v1

License: (c) (1) This work is licensed under a Creative Commons Attribution 4.0 International License. Read Full License 


\section{Abstract}

Background: The negative impact of caregiving on carers' physical and psychological wellbeing is well documented. Carers of mental health inpatients face additional burden, and report predominantly negative experiences of inpatient services. It remains unclear why, despite policies intended to improve inpatient experiences. A comprehensive review of carers' inpatient experiences is needed to understand carer needs. As such, we aimed to conduct a systematic review and thematic synthesis of carer experiences of inpatient mental health care.

Methods: We searched MEDLINE, PsycINFO, Embase and CINAHL for qualitative studies examining carer experiences of mental health inpatient care. Searches were supplemented by reference list screening and forward citation tracking of included studies. Results were synthesised using thematic synthesis. Our protocol was registered on PROSPERO (CRD42020197904) and our review followed Preferred Reporting Items for Systematic Reviews and Meta-Analyses guidelines.

Findings: 12 studies were included from 6 countries. Four themes were identified: the emotional journey of inpatient care, invisible experts, carer concerns about quality of care for their loved one and relationships and partnership

Interpretation: Greater attention must be paid to ensure carers are well-supported, well-informed, and included in care. More emphasis must be placed on fostering positive relationships between carers, service users and staff and in facilitating continuity of care across inpatient and community services to provide carers with a sense of security and predictability. Further research is needed to explore differences in experiences based on carer and service user characteristics and global context, alongside co-production with carers to develop and evaluate future guidelines and policies.

\section{Research In Context}

\section{Evidence before this study}

Caregivers of mental health inpatients consistently report negative experiences with inpatient services. It remains unclear why this persists, despite policies intended to improve their experiences. Existing reviews have not considered carer views of the experience itself or excluded experiences with voluntary hospitalisations. As such, this review aimed to explore carer experiences of routine inpatient mental healthcare. MEDLINE, PsycINFO, Embase and the Cumulative Index to Nursing and Allied Health Literature (CINAHL) were searched from inception to February 2021. Studies were included if they employed qualitative methodology, had a sample consisting of at least $90 \%$ carers, reported on the experiences of carers with adult (18+) mental health inpatient care and were published in English in a peer-reviewed journal. All studies were of high quality.

\section{Added value of this study}

This systematic review and thematic synthesis suggests that carer experiences with inpatient services continue to be characterized by emotional turmoil, a lack of support and exclusion from and dissatisfaction with care. Furthermore, it was suggested that positive relationships between staff and carers and between staff and service users, continuity of care, and acknowledging carers as both humans and experts are essential to improving carer experiences with inpatient care.

\section{Implications of all the available evidence}

Our review suggests that there is a need for greater continuity across inpatient and community services and that inpatient staff must make greater attempts to foster positive relationships and to ensure carers are well supported, informed and included. Further research is needed to explore the impact of service user and carer characteristics on carer experiences. There is also a need for co-production with carers in the development and evaluation of policies intended to improve inpatient services to meet carer needs.

\section{Introduction}

The shift in psychiatric care towards community care and deinstitutionalisation ${ }^{1-4}$ has resulted in family members increasingly taking on the burden of care for loved ones with mental health difficulties. ${ }^{5-7}$ In the UK alone, there are an estimated 6.8 million informal carers who, through their unpaid care, save the UK approximately $£ 132$ billion annually. ${ }^{8}$ There is clear evidence of the benefits of carer involvement for individuals experiencing mental health difficulties, with higher carer involvement being associated with reductions in symptoms, risk of relapse and inpatient admissions. ${ }^{9-12}$ However, caregiving can have pervasive and enduring detrimental effects with higher rates of common mental disorder and physical health difficulties in carers. ${ }^{13-15}$

Deinstitutionalisation has also led to significant changes in inpatient mental health services, which provide support to those experiencing mental health crises so severe they cannot be managed or treated in the community. ${ }^{16,17}$ Throughout the years, these units have seen a $73 \%$ reduction in beds from 1987 to 2019. ${ }^{18}$ In turn, this has led to a significant change in the profile of mental health inpatients, with only the most severe presentations, often with comorbidities and social difficulties, being admitted. ${ }^{18,19}$ Thus, being a carer of a mental health inpatient is likely to come with added challenges. Instead of inpatient admission being a time wherein carers obtain respite from caregiving, research has demonstrated that it becomes a time of increased stress ${ }^{20}$ with inpatient carers reporting significantly higher burden than carers of outpatients. ${ }^{21}$

In recognition of these issues, UK policies such as the National Carers Strategy and NHS Triangle of Care have encouraged the support of and collaboration with carers. ${ }^{22,23}$ However, carers' qualitative accounts continue to depict predominantly negative experiences of inpatient services, characterized by a lack of support and exclusion from their loved one's care. ${ }^{21,24-31}$ For example, carers report feeling excluded from the processes of admission, treatment and 
discharge planning. ${ }^{24,28}$ Nonetheless, carers consistently indicate a desire to be valued, to work in collaboration with inpatient staff, and for greater support in managing financial burdens, their physical and mental health, and their loved one's mental health. ${ }^{25,31-35}$

There have been a number of qualitative reviews which have examined the impact of psychiatric hospitalisation on carers including mixed methodology papers ${ }^{36}$, and qualitative-focused reviews examining carer experiences of mental health crises ${ }^{37}$ and detention under mental health legislation. ${ }^{38}$ However, these reviews did not examine the subjective experience of family and carers using qualitative synthesis methodology, ${ }^{36}$ or excluded experiences with voluntary hospitalisations. ${ }^{37,38}$ However, as routine inpatient care includes both voluntary and involuntary admissions, ${ }^{39}$ to exclude carer experiences of either is to paint an incomplete picture. This review seeks to fill this gap and aims to explore carer experiences of routine inpatient mental healthcare.

\section{Method}

\section{Design}

We conducted a systematic review and thematic synthesis of qualitative literature exploring carer experiences of mental health inpatient care. Our protocol was registered on PROSPERO (CRD42020197904) and the review was conducted in accordance with best practice guidance as outlined by the Preferred Reporting Items for Systematic Reviews and Meta-Analyses (PRISMA). ${ }^{40}$

\section{Search strategy and selection criteria}

Searches were conducted on Embase, Medline, PsycINFO and CINAHL in June 2020, and updated in February 2021. This allowed us to cover a broad range of multidisciplinary clinical evidence. Searches contained keywords pertaining to the relevant sample (carers, caregivers, parents, fathers, mothers, spouses, wives, husbands), mental health context (inpatient, acute, psychiatric, mental health, hospitalisation, ward), and study design (qualitative, interviews, focus groups). Full search strategies for each database are available in the supplementary material. Searches were supplemented by screening reference lists and forward citation tracking of included studies to reduce the chance of missing relevant studies.

Studies were included if they: (a) used semi-structured interviews or focus groups; (b) had a sample that consisted of majority carers (at least $90 \%$ ); (c) reported on the experiences of carers with adult (18+) mental health inpatient care (d) were published in English in a peer-reviewed journal.

Studies were excluded if they: (a) examined a discrete component of inpatient care e.g., admission under the Mental Health Act (b) reported on experiences with services for children and young people, intellectual and/or learning disabilities, older adults or forensic services; (c) utilised surveys or questionnaires; (d) were reported in conference abstracts, books, editorials or general commentary.

\section{Data screening and extraction}

All titles and abstracts were screened by NAS, with a random $20 \%$ being reviewed by an additional independent reviewer. Full texts were then screened for inclusion by NAS with any disagreements discussed with LW. Where additional information was required to determine eligibility, authors were contacted for clarification. The following information was extracted from each included study: (1) authors, (2) country where research was conducted, (3) study aim, (4) sample size \& characteristics (including age, nature of relationship with service user and gender), (5) the data collection method and (6) the analytic approach utilised.

\section{Quality appraisal}

Quality appraisal was conducted using the Critical Appraisal Skills Programme (CASP) qualitative checklist. ${ }^{41}$ This is a deviation from the registered protocol, as after consultation with an expert in qualitative methodology (NM) we considered it more appropriate. This checklist examines whether studies included sufficient description and justification of the chosen methods of data collection, sampling, and analytical approach, as well as whether sufficient attention was given to ethics and the role of the researchers involved. In accordance with guidelines for thematic synthesis, no studies were excluded on the basis of quality. 42,43

\section{Data synthesis}

The thematic synthesis of qualitative research in psychiatry as outlined by Lachal et al. ${ }^{42}$ and adapted from Thomas $\&$ Harden ${ }^{43}$ was used to guide analysis. The results section of each study, including verbatim carer quotes and author analysis, was extracted and used as data. This was then exported into NVivo12 for thematic analysis. ${ }^{44}$ To start, data was read and re-read by NAS to achieve sufficient familiarisation, and ultimately immersion, with the data. An initial coding frame was developed using half of the included studies and was further developed through the identification of shared themes while coding the second half of studies. Themes were derived from the data as per inductive methodology, and then synthesised across studies to develop overarching themes and sub-themes that would capture carer experiences of inpatient mental healthcare.

\section{Results}

\section{Search Results}

The search yielded 3237 articles after the removal of duplicates. Out of the 48 studies selected for full-text screening, a further 38 were excluded due to not meeting the eligibility criteria. Two additional eligible studies were identified using forward citation tracking, resulting in a total of 12 studies included in the final synthesis. The search process is outlined in figure 1. 


\section{Study Characteristics}

Table 1 shows the characteristics of included studies. The total number of carers included was 165, with sample sizes ranging from 3 to 31 . Carers were predominantly female $(60 \%)$, parents $(63 \%)$, and from White ethnic backgrounds $(68 \%)$. For data collection, studies utilised interviews ( $\mathrm{n}=10)$, discussion groups $(n=1)$ and a combination of both $(n=1)$. All included studies were of high quality, with CASP scores ranging from 8 to 10 (median score $=8)$ out of a maximum score of 10 .

\section{Thematic Synthesis}

Four overarching themes were identified: the emotional journey of inpatient care, invisible experts, carer views on quality of care for their loved one, and relationships \& partnership (Table 2).

\section{The Emotional Joumey of Inpatient Care}

The emotional journey of inpatient care was discussed in nearly all studies $(n=10) .{ }^{24-26,32,33,45-47,49,51}$

\section{A. The build up to hospitalisation}

The build up to hospitalisation was described as distressing and overwhelming, as carers find themselves having to juggle managing the deterioration of their loved one's condition while navigating the mental health system to get help. Carers report feeling powerlessness and frustration that help was seemingly only made available once their loved one had deteriorated to a point where hospitalisation was inevitable.

"I mean one day he had me in tears, I had to walk out of the house and I just walked into the police station and I spoke to somebody on the desk, and they gave me a little bit of advice and they told me who to contact and stuff, and the next day I rang, I actually spoke to somebody but even that was a long process. I phoned them one day and they said they would get back to me and I said like, I need help now not like tomorrow or next week. I think like they got back to me three months later, it was really, really hard to get any kind of help to start with."

$(\text { Carer })^{24}$

\section{B. Hospital Care}

Once their loved one was hospitalised, carers reported experiencing a mixture of conflicting emotions such as relief, guilt, fear, and hope. Carers were hopeful to obtain some respite from caregiving, and for their loved one to receive appropriate treatment and containment.

"Participants' accounts of hospitalisation framed it overwhelmingly as an appropriate intervention that brought relief and respite. The young person was understood to be physically contained, with access to appropriate treatment, and hospital was seen as a place of safety, for self and society."

(Authors) $)^{47}$

Carers also reported a strong fear regarding the quality of inpatient care, their loved one's safety, their ability to care for the service user after discharge, how they will be judged by others.

"The mothers expressed that they often felt as if they were being judged as parents who were trying to 'get rid of the problem."'

(Author \& Carers) $)^{26}$

\section{Invisible Experts}

Carers' feelings of invisibility and neglect by mental health professionals, as well as their exclusion from their loved one's care during hospitalisation were reported as central to carer's experiences with inpatient care across studies that took place in the UK, Canada and Australia ( $\mathrm{n}=7) .{ }^{24-26,33,47,50,51}$

\section{A. The invisibility \& neglect of carer needs}

Despite the significant emotion toll of the hospitalisation and a heightened need for support, carers report that their needs were seldom acknowledged and strongly perceived inpatient staff as unsupportive. Moreover, carers felt uniformed about the loved one's treatment and wanted more information on mental illness and how to manage illness-related behaviours.

"Interestingly, the families clearly did not perceive staff as being supportive... they were seldom, if ever, acknowledged when they visited their child... when asked outright if they found the health care providers to be supportive, they answered resoundingly, 'No'."

(Authors) 33

Although rare $(n=3)$, when carers did feel supported and were given the opportunity to obtain clear and accessible information, they found the inpatient experience more positive and reported tremendous relief. ${ }^{25,48,50}$

\section{B. Exclusion of carers from loved one's care}


Despite being expected to care for the service user throughout hospitalisation, and being experts in their own right, carers felt excluded from inpatient care. Carers want to be included in decision-making and found the lack of communication and information frustrating. Even when carers were invited to care planning meetings, they describe a resignation to their inability to affect change, as inpatient staff were deemed the sole experts. This was particularly contentious during discharge planning. Information sharing was also seen as non-reciprocal, with carers being relied on to provide information, but not being provided any in return. Confidentiality was cited as an issue here, with carers viewing it as an excuse used to exclude them.

"I wasn't involved, I was an afterthought ... no one told us anything, no one rang to keep us up to date with the plan of care. I only found out that he (son) had been started on an injection when he rang to tell me that he'd had a needle in his bum... How can I look after him at home if I don't know what I'm supposed to be doing?"

$(\text { Carer })^{25}$

Carers who were included in the treatment process $(n=2)$ had considerably more positive views of the inpatient experience and felt empowered and confident to care for their loved one after discharge. ${ }^{25,51}$

\section{Carer concerns about quality of care for their loved one}

Carers reported concerns about the quality of inpatient care across the majority of studies $(n=7) .24,26,45,48,47,50,51$ Carers spoke of dissatisfaction relating to delays, unmet service user needs, staff competence, the duration of hospitalisation, safety and the lack of space. As a result, carers felt that appropriate and timely help was not being provided. Carers were also displeased with the heavy focus on medicating the service user, noting that no one really spoke to their loved one.

"All she does is see a doctor once or twice a week. There's no counsellor brought in [...] She seriously needs to talk to somebody, not for 10 minutes, how you're going, how you're feeling, are you still seeing anything? That's all she gets. She's never actually sat down with anybody and just talked about anything."

$(\text { Carer })^{51}$

Moreover, carers views on staff competence and the degree to which they trusted the treatment plan played an important role in influencing views on care. They consistently spoke of disagreement with the duration of hospitalisation, and that sufficient help was not actually received during hospitalisation.

"This disagreement with the clinicians' assessment regarding the level of professional support required was noticeable before discharge and it contributed to the burden of care shifted from services... More specifically, family caregivers commonly believed that the patient should have been admitted earlier or discharged later, and this was a concern reported mainly by family caregivers of patients with previous hospital admissions."

(Authors) ${ }^{24}$

\section{Relationships \& Partnership}

Carers describe relationships between carers, service users and staff as being integral to their experiences of inpatient care ( $n=9) .24,26,33,45-48,50,51$

\section{A. Carers \& their loved one: Distance and strain}

Carers reported that with the hospitalisation, a strain was placed on their relationship with the service user. For some, this was linked to blame, either from the service user blaming the carer for the hospitalisation, or the carer blaming the service user for their mental health difficulties.

"He had this great hatred of me, whatever it was, so it was very difficult for me, it was a great hate. And I think it stemmed from I was the one, I actually put him into the hospital."

$(\text { Carer })^{47}$

Others cited an inability to visit their loved one as often as desired due to practical difficulties such as other life responsibilities or rigid visiting hours, which was distressing for both parties.

"The more complicated public transport route, using more buses, the extra cost of the travelling, and the fact that "sometimes your benefits get reduced after you have been in [the hospital] for so long" were all issues relating to the location of the hospital, which was felt to prohibit regular visiting..."'

(Authors \& Carer) $)^{50}$

\section{B. Carers \& staff: A desire for partnership}

Carers relationship with staff also played an important role in their experience. They described the relationship as marked with tension and reported sensing a divide of "us vs them", wherein they were viewed as threats, challenging, or nuisances. Nonetheless, carers consistently expressed a desire for partnership with staff, citing their belief that this would ultimately foster a better inpatient experience for both carers and service users. Carers felt that continuity of staff would facilitate partnership, as they would feel more at ease expressing themselves with staff they were familiar with.

"It's about working together, the team knowing that I have valuable things to contribute and vice versa, because we all want the same at the end of the day."

Page 5/13 
$(\text { Carer })^{25}$

\section{C. Service users \& staff: $A$ need for affection}

Equally important to carers was the relationship between service users and staff. They spoke of wanting staff to be more affectionate and caring to their loved one, to actively listen and talk to them, and to help them with self-care.

Amy was distressed that her husband would sometimes get "very upset going back to the [Old] hospital" after she had accompanied him outside the hospital on "leave"... if a member of staff took the time to talk to her husband, to welcome him back ... her "husband would go in bouncy instead of going up to his room and crying, and that made a huge difference".

(Authors \& Carer) $)^{50}$

\section{Discussion}

\section{Summary of Findings}

Our thematic synthesis highlighted the distressing and overwhelming nature of the buildup to hospitalisation for carers. They describe struggling to manage the deterioration of their loved one's condition while attempting to obtain help within a confusing mental health system. Once their loved one was hospitalised, carers describe emotional conflict, with initial relief associated with respite from caregiving but also guilt and fear. Carers were also quickly disillusioned with the quality of care provided, particularly the lack of timely and appropriate help. These findings have been identified in similar reviews. ${ }^{36-38}$

Our synthesis suggests that carers' lack of support and exclusion from their loved one's care are integral to their experience. Carers report perceiving inpatient staff as insensitive to their emotional needs and felt unsupported, uninformed, and unacknowledged throughout the hospitalisation. Carers desperately wanted more information on the illness and treatment plan and wanted greater involvement throughout treatment and discharge planning. This lack of participation and information is also consistent with the aforementioned reviews. ${ }^{37,38}$

Our findings suggest that collaborative relationships hold the potential to transform inpatient experiences. Carers describe a distance and strain placed on their relationship with the service user, and the distress this causes for both parties, supporting previous reviews. ${ }^{36,38}$ Similarly, carers often described their relationship with staff as marked by tension and dismissal. Although rare, when carers felt included, they describe a much more positive inpatient experience, as well as confidence in their own caregiving abilities, in line with previous research. ${ }^{38}$ An important finding derived from our synthesis is the importance placed by carers on the relationship between service users and staff, with carers wanting staff to be more caring to their loved one. When this occurred, they described it as therapeutic both to them and the service user.

The importance of acknowledging carers, both as humans and experts, was suggested as essential to improving carer experiences with inpatient care. As such, greater attempts should be made by professionals to understand the unique needs of carers and how to best meet them, particularly soon after the hospitalisation of their loved one, as this was suggested to be a particularly vulnerable time. Here, there is a need for more accessible information; carers should be provided with psychoeducation regarding their loved one, as well as information on how to manage their own wellbeing. Additionally, inpatient staff should be more proactive in attempts to include carers in care planning, particularly surrounding discharge. Within this, professionals should acknowledge carers expertise on their loved one, which would in turn foster a sense of partnership and help break down the divide reported by carers between them and staff. There is also a need for greater continuity across inpatient and community services. While continuity of care is often thought of in relation to its importance to service users, ${ }^{52}$ our findings suggest that it is equally important to carers.

Future research should attempt to explore whether differences in carer and service user characteristics influence carer experiences. An area of focus should be the examination of the experiences of carers of ethnic minorities, as this group tends to be underrepresented. Additionally, as many participants in studies in this area tend to be parents, and particularly mothers, greater attempts should be made to explore different carer-service user relationships. Future research would also benefit from greater co-production with carers in the development and evaluation of policies that intend to help inpatient services better meet carer needs.

The primary strength of this study was the methodological rigor. For example, this review was registered with PROSPERO, followed PRISMA guidelines, and searches were conducted across an array of databases, allowing us to cover a broad range of clinical evidence. Moreover, all the included studies included in the review were of high quality, as demonstrated by high scores on the CASP checklist.

However, there are several limitations to be noted. First, our analysis is dependent upon study authors' interpretation and presentation of their original qualitative data. This meant that we were unable to analyse differences in experiences based on the characteristics of carers or service users (e.g. ethnicity, diagnosis), as these distinctions were not made in the included studies. Second, despite the consistency of themes across studies, their limited geographical spread means that it is unlikely that our findings represent experiences of carers in different geographical contexts and mental healthcare systems. Third, as we only included studies published in peer-reviewed publications it is possible that we have missed relevant findings. Finally, we were unable to obtain input from individuals with lived experience of informal caregiving in the development of the project due to limited time and resources.

In summary, our review highlights that carer experiences are still marked by emotional turmoil, a lack of support and exclusion from and dissatisfaction with care. Our review suggests that there is a need for greater continuity across inpatient and community services and that inpatient staff must make greater attempts to foster positive relationships and to ensure carers are well supported, informed and included. 


\section{Declarations}

Ethics approval and consent to participate: Not applicable.

Consent for publication: Not applicable.

Availability of Data and Material: Data sharing is not applicable to this article as no datasets were generated or analysed during the current study.

Competing interests: None

Funding Statement: This research received no specific grant from any funding agency, commercial or not-for-profit sectors

Author contribution: NAS led on this study and drafted the manuscript. LW and NM inputted into the design of the study, provided supervisory support and contributed to the manuscript draft.

Acknowledgements: None

\section{References}

1. Magliano L, Mcaid D, Kirkwood S, Berzins K. Carers and families of people with mental health problems. In: Knapp M, Mcaid E, Mossialos E, Thornicroft, G, eds. Mental health policy and practice across Europe. Berkshire: McGraw-Hill; 2007. p. 374-96.

2. Brennan A, Warren N, Peterson V, Hollander Y, Boscarato K, Lee S. Collaboration in crisis: Carer perspectives on police and mental health professional's responses to mental health crises. Int J Ment Health Nurs 2016 ;25(5):452-61.

3. Chan SW. Global perspective of burden of family caregivers for persons with schizophrenia. Arch Psychiatr Nurs. 2011;25(5):339-49.

4. Sealy PA. The impact of the process of deinstitutionalization of mental health services in Canada: an increase in accessing of health professionals for mental health concerns. Soc Work Public Health 2012; 27(3):229-37.

5. Parker G. \& Clarke H. Making ends meet: Do carers and disabled people have a common agenda. Policy and Politics 2002; 30:347-59.

6. Lloyd, M. \& Carson, A. Culture shift: Carer empowerment and cooperative enquiry. J Psychiatr Ment Health Nurs 2005; 12:187-191.

7. Laursen, T. M. (2011). Life expectancy among persons with schizophrenia or bipolar affective disorder. Schizophr Res 2011; 131:101-104.

8. Carers UK. Valuing Carers 2015: The rising value of carers' support. 2015. https://www.carersuk.org/for-professionals/policy/policy-library/valuing-carers2015 (accessed 12th September 2020)

9. Tempier R, Balbuena L, Lepnurm M, Craig TK. Perceived emotional support in remission: results from an 18-month follow-up of patients with early episode psychosis. Soc Psychiatry Psychiatr Epidemiol 2013; 48: 1897-904.

10. Fleury MJ, Grenier G, Caron J, Lesage A. Patients' report of help provided by relatives and services to meet their needs. Community Ment Health $J 2008$; 44: $271-81$.

11. Scofield N, Quinn, J., Haddock, G., \& Barrowclough, C. Schizophrenia and substance misuse problems: a comparison between patients with and without significant carer contact. Soc Psychiatry Psychiatr Epidemiol 2001; 36: 523-8.

12. Norman RM, Malla AK, Manchanda R, Harricharan R, Takhar J, Northcott S. Social support and three-year symptom and admission outcomes for first episode psychosis. Schizophr Res 2005; 80: 227-34.

13. Shah, Wadoo \& Latoo. Psychological Distress in Carers of People with Mental Disorders. Br. J. Med. Pract 2010; 3(3): a327.

14. Stansfeld S, Smuk M, Onwumere J, et al. Stressors and common mental disorder in informal carers - An analysis of the English Adult Psychiatric Morbidity Survey 2007. Soc Sci Med 2014; 120: 190-8.

15. Smith L, Onwumere J, Craig T, McManus S, Bebbington P, Kuipers E. Mental and physical illness in caregivers: Results from an English national survey sample. Br J Psychiatry 2014; 205:197-203.

16. Joint Commissioning Panel for Mental Health. Guidance for commissioners of acute care - inpatient and crisis home treatment. 2013. https://www.jcpmh.info/wp-content/uploads/jcpmh-acutecare-guide.pdf (accessed 12th September 2020).

17. Crisp N. (2015). Improving acute inpatient psychiatric care for adults in England. 2015. http://media.wix.com/ugd/0e662e_a93c62b2ba4449f48695ed36b3cb24ab.pdf (accessed 12th September 2020).

18. Royal College of Psychiatrists, Strategy Unit. Exploring Mental Health Inpatient Capacity across Sustainability and Transformation Partnerships in England. 2019. https://www.strategyunitwm.nhs.uk/sites/default/files/2019-

11/Exploring\%20Mental\%20Health\%20Inpatient\%20Capacity\%20accross\%20Sustainability\%20and\%20Transformation\%20Partnerships\%20in\%20Englan \%20191030_1.pdf (accessed 12th September 2020)

19. McCrone P, Dhanasiri S, Patel A, Knapp M, Lawton-Smith S. Paying the price: the cost of mental health care in England to 2026.2018.

https://www.kingsfund.org.uk/sites/default/files/Paying-the-Price-the-cost-of-mental-health-care-England-2026-McCrone-Dhanasiri-Patel-Knapp-LawtonSmith-Kings-Fund-May-2008_0.pdf (Accessed 12th September 2020).

20. Wynaden D, Orb A. Impact of patient confidentiality on carers of people who have a mental disorder. Int J Ment Health Nurs 2005; 14: 166-71.

21. Cleary M, Freeman A, Hunt G, Walter G. What patients and carers want to know: An exploration of information and resource needs in adult mental health services. Aust N Z J Psychiatry 2005; 39: 507-13. 
22. Department of Health. Recognised, Valued and Supported: Next Steps for The Carers Strategy. 2010.

https://www.gov.uk/government/uploads/system/uploads/attachment_data/file/213804/dh_122393.pdf> (accessed 12 ${ }^{\text {th }}$ September 2020)

23. Worthington A, Rooney P. Triangle of care, carers included: A guide to best practice in acute mental health care. National Mental Health Development Unit. 2010. http://its-services.org.uk/silo/files/triangle-of-care-carers-included.pdf (accessed $12^{\text {th }}$ September 2020).

24. Jankovic J, Yeeles K, Katsakou C, et al. Family caregivers' experiences of involuntary psychiatric hospital admissions of their relatives-a qualitative study. PloS ONE 2011; 6(10: e25425.

25. Wilkinson C, McAndrew S. 'I'm not an outsider, I'm his mother!' A phenomenological enquiry into carer experiences of exclusion. Int $J$ Ment Health Nurs. 2008;17(6):392-401.

26. Crisanti AS. Experiences with involuntary hospitalization: a qualitative study of mothers of adult children with schizophrenia. Schizophr Res 2000; 45 : 79 $-81$.

27. Longo S, Scior K. In-patient psychiatric care for individuals with intellectual disabilities: the service users' and carers' perspectives. J Ment Health 2004; 13: $211-21$.

28. O'Brien L, Cole R. Mental health nursing practice in acute psychiatric close observation areas. Int J Ment Health Nurs 2004; 13:89-99.

29. Rose L, Mallinson RK, Walton-Moss B. Barriers to family care in psychiatric settings. J Nurs Scholarsh 2004; 36:39-47

30. Jubb M, Shanley E. Family involvement: The key to opening locked wards and closed minds. Int J Ment Health Nurs 2002; 11:47-53.

31. Solomon P, Marcenko M. Families of adults with severe mental illness: Their satisfaction with inpatient and outpatient treatment. Psychiatr Rehabil J 1992; 16(1): 121-34.

32. Jagannathan A, Thirthalli J, Hamza A, Hariprasad VR, Nagendra HR, Gangadhar BN. A qualitative study on the needs of caregivers of inpatients with schizophrenia in India. Int J Soc Psychiatry. 2011;57(2):180-94.

33. Clarke D, Winsor J. Perceptions and Needs of Parents during a Young Adult's First Psychiatric Hospitalization: "We're All on This Little Island and We're Going to Drown Real Soon". Issues Ment Health Nurs 2010, 31(4):242-47.

34. Angermeyer MC, Diaz Ruiz de Zarate J, Matschinger H. Information and support needs of the family of psychiatric patients. Gesundheitswesen 2000; 62(10): 483-6

35. Chien WT, Norman I. (2003) Educational needs of families caring for Chinese patients with schizophrenia. J Adv Nurs 2000; 44(5): 490-98

36. Weller BE, Faulkner M, Doyle O, Daniel SS, Goldston DB. Impact of patients' psychiatric hospitalization on caregivers: a systematic review. Psychiat serv, 2015 66(5): 527-35.

37. Lavoie, JA. Relative invisibility: an integrative review of carers' lived experiences of a family member's emergency mental health crisis. Soc Work Ment Health 2018; 16(5): 601-26.

38. Stuart R, Akhter S, Machin K, et al. Carers' experiences of involuntary admission under mental health legislation: Systematic review and qualitative metasynthesis. BJPsych Open 2020; 6(2): E19.

39. The NHS Confederation. Defining mental health services: promoting effective commissioning and supporting QIPP. 2012. https://www.nhsconfed.org/ /media/Confederation/Files/Publications/Documents/Defining_mental_health_services.pdf (accessed 12th September 2020)

40. PRISMA: Moher D, Liberati A, Tetzlaff J, Altman DG, The PRISMA Group Preferred Reporting Items for Systematic Reviews and Meta-Analyses: The PRISMA Statement. BMJ 2009; 339: b2700

41. Critical Appraisal Skills Programme CASP Qualitative Checklist. 2018. https://casp-uk.net/wp-content/uploads/2018/01/CASP-Qualitative-Checklist2018.pdf (accessed 12th September 2020)

42. Lachal J, Revah-Levy A, Orri M and Moro MR. Metasynthesis: An Original Method to Synthesize Qualitative Literature in Psychiatry. Front Psychiatry 2017; 8: 269. 00269

43. Thomas J, Harden A. Methods for the thematic synthesis of qualitative systematic reviews. BMC Med Res Methodo/ $2007 ; 8: 45$.

44. Braun V, Clarke V. Using thematic analysis in psychology. Qual Res Psychol 2006; 3: 77-101.

45. da Silva Andrade A, Cardoso BD, de Souze JEAP, de Campos MC, de Lima GZ, Buriola AA. "Feelings of relatives of patients hospitalized in the psychiatric emergency care unit: a look on the family". Cuidado E Saúde 2016;15(2): 268-74.

46. Guimaraes AN, Schneider JF, Camattall, MW, Nasill, C, Ferrazi L, de Pinholl LB. Psychiatric hospitalization of alcoholists from rural areas in a general hospital: expectations of families. Rev Bras Enferm 2019;72(6): 1442-9.

47. Hickman G, Newton E, Fenton K, Thompson J, Boden ZV, Larkin M. The experiential impact of hospitalisation: Parents' accounts of caring for young people with early psychosis. Clin Child Psychol Psychiatry 2016; 21(1): 145-55.

48. Fernandes Moll M, Pires FC, Ventura CAA, Boff NN, da Silva NF. Psychiatric Nursing Care in a General Hospital: Perceptions and Expectations of the Family/Caregiver. J Psychosoc Nurs Ment Health Serv 2018; 8:31-6

49. Park M, Lee KJ. Korean Sibling Caregivers of Individuals Diagnosed with Schizophrenia. Asian Pac Is/ Nurs J 2017; 2(3):97-102.

50. Wood VJ, Curtis SE, Gesler W, et al. Creating 'therapeutic landscapes' for mental health carers in inpatient settings: a dynamic perspective on permeability and inclusivity. Soc Sci Med 2013; 91:122-29.

51. Wyder M, Bland R, McCann K \& Crompton D. The Family Experience of the Crisis of Involuntary Treatment in Mental Health, Aust Soc Work 2018; 71(3): 319-31. 
52. Biringer E, Hartveit M, Sundfor B, Ruud R, Bog M. Continuity of care as experienced by mental health service users - a qualitative study. BMC Health Serv Res 2017; 17: 763

\section{Tables}

Table 1: Study characteristics 


\begin{tabular}{|c|c|c|c|c|c|c|}
\hline Authors & Country & Aim & Sample size \& characteristics & $\begin{array}{l}\text { Data } \\
\text { collection } \\
\text { method }\end{array}$ & Analytic approach & $\begin{array}{l}\text { CASP } \\
\text { Score } \\
(\max \\
10)\end{array}$ \\
\hline $\begin{array}{l}\text { Clarke \& } \\
\text { Winsor } \\
(2010)^{33}\end{array}$ & Canada & $\begin{array}{l}\text { Exploring the perceptions } \\
\text { and needs of parents during } \\
\text { a young person's first } \\
\text { psychiatric hospitalization. }\end{array}$ & $\begin{array}{l}\mathrm{N}=10 \\
\text { Nature of relationship: } 9 \text { mothers, } 1 \text { father } \\
\text { M/F: } 9 / 1 \\
\text { Age } 40-59\end{array}$ & $\begin{array}{l}\text { Semi- } \\
\text { structured } \\
\text { interviews }\end{array}$ & $\begin{array}{l}\text { Morse \& Field's } \\
\text { four processes }\end{array}$ & 8 \\
\hline $\begin{array}{l}\text { Crisanti } \\
(2000)^{26}\end{array}$ & Canada & $\begin{array}{l}\text { Examining mothers' } \\
\text { experiences with the } \\
\text { involuntary hospitalization } \\
\text { of their adult child with } \\
\text { schizophrenia. }\end{array}$ & $\begin{array}{l}\mathrm{N}=3 \\
\text { Nature of relationship: } 3 \text { mothers } \\
\text { M/F: } 0 / 3 \\
\text { Patient diagnosis: } 3 \text { schizophrenia } \\
\text { Patient illness duration: } 12-20 \text { years }\end{array}$ & $\begin{array}{l}\text { Semi- } \\
\text { structured } \\
\text { interviews }\end{array}$ & $\begin{array}{l}\text { Phenomenology } \\
\text { (VanKaam's) }\end{array}$ & 8 \\
\hline $\begin{array}{l}\text { Da Silva } \\
\text { Andrade et } \\
\text { al. }(2016)^{45}\end{array}$ & Brazil & $\begin{array}{l}\text { Examining the feelings of } \\
\text { relatives of individuals } \\
\text { admitted to a psychiatric } \\
\text { emergency care unit. }\end{array}$ & $\begin{array}{l}\mathrm{N}=20 \\
\mathrm{M} / \mathrm{F}: 9 / 11 \\
\text { Age: } 40-65\end{array}$ & $\begin{array}{l}\text { Semi- } \\
\text { structured } \\
\text { interviews }\end{array}$ & $\begin{array}{l}\text { Thematic content } \\
\text { analysis (Bardin's) }\end{array}$ & 8 \\
\hline $\begin{array}{l}\text { Guimaraes et } \\
\text { al. }(2017)^{46}\end{array}$ & Brazil & $\begin{array}{l}\text { Exploring the expectations } \\
\text { of family members of } \\
\text { alcoholics admitted to the } \\
\text { Psychiatric Hospitalization } \\
\text { Unit. }\end{array}$ & $\begin{array}{l}\mathrm{N}=15 \\
\text { Nature of relationship: } 4 \text { mothers, } 4 \\
\text { brothers, } 2 \text { sisters, } \\
2 \text { sons, } 1 \text { daughter, } 1 \text { grandfather, } 1 \text { son-in- } \\
\text { law } \\
\text { M/F: } 8 / 7 \\
\text { Age: } 25-73 \\
\text {-- } \\
\text { Patient diagnosis: } 15 \text { alcohol use disorder }\end{array}$ & $\begin{array}{l}\text { Semi- } \\
\text { structured } \\
\text { interviews }\end{array}$ & $\begin{array}{l}\text { Phenomenological } \\
\text { Sociology }\end{array}$ & 8 \\
\hline $\begin{array}{l}\text { Hickman et } \\
\text { al. }(2016)^{47}\end{array}$ & UK & $\begin{array}{l}\text { Examining the experiential } \\
\text { impact of hospitalisation on } \\
\text { the parents of young people } \\
\text { with early psychosis. }\end{array}$ & $\begin{array}{l}\mathrm{N}=6 \\
\text { Nature of relationship: } 4 \text { mothers and } 2 \\
\text { fathers } \\
\text { M/F: } 4 / 2 \\
\text {-- } \\
\text { Patient diagnosis: } 6 \text { psychosis }\end{array}$ & $\begin{array}{l}\text { Semi- } \\
\text { structured } \\
\text { interviews }\end{array}$ & $\begin{array}{l}\text { Interpretative } \\
\text { Phenomenological } \\
\text { Analysis }\end{array}$ & 9 \\
\hline $\begin{array}{l}\text { Jagannathan } \\
\text { et al. } \\
(2011)^{32}\end{array}$ & India & $\begin{array}{l}\text { Exploring the needs of } \\
\text { caregivers of inpatients with } \\
\text { schizophrenia. }\end{array}$ & $\begin{array}{l}\mathrm{N}=30 \\
\text { Nature of relationship: } 21 \text { parents, } 4 \\
\text { siblings, } 3 \text { "other", } 2 \text { spouses } \\
\text { M/F: } 13 / 17 \\
\text {-- } \\
\text { Patient diagnosis: } 30 \text { schizophrenia }\end{array}$ & $\begin{array}{l}\text { Focus group } \\
\text { discussions }\end{array}$ & "Iteration" & 8 \\
\hline
\end{tabular}




\begin{tabular}{|c|c|c|c|c|c|c|}
\hline Authors & Country & Aim & Sample size \& characteristics & $\begin{array}{l}\text { Data } \\
\text { collection } \\
\text { method }\end{array}$ & Analytic approach & $\begin{array}{l}\text { CASP } \\
\text { Score } \\
(\max \\
10)\end{array}$ \\
\hline $\begin{array}{l}\text { Jankovic et } \\
\text { al. }(2011)^{24}\end{array}$ & UK & $\begin{array}{l}\text { Examining family } \\
\text { caregivers' experience of the } \\
\text { involuntary admission of } \\
\text { their relative. }\end{array}$ & $\begin{array}{l}\text { N=31 } \\
\text { Nature of relationship: } 16 \text { parents, } 7 \\
\text { partners, } 4 \text { siblings, } 2 \text { children, } 1 \\
\text { grandmother, } 1 \text { "elderly relative" } \\
\text { M/F: 12/19 } \\
\text { Age: } 18-59 \\
\text { Ethnicity: } 21 \text { White, } 10 \text { Asian, Black, or } \\
\text { Mixed } \\
\text { - } \\
\text { Patient diagnosis (on discharge): } 8 \\
\text { schizophrenia, } 6 \text { bipolar disorder, } 2 \\
\text { recurrent depressive disorder, } 1 \\
\text { schizoaffective disorder, } 1 \text { "manic } \\
\text { episode", } 1 \text { borderline personality disorder, } \\
1 \text { "no mental illness on discharge", } 2 \\
\text { "unavailable" }\end{array}$ & $\begin{array}{l}\text { Semi- } \\
\text { structured } \\
\text { interviews }\end{array}$ & Thematic analysis & 9 \\
\hline & & & First hospitalisation: 12 & & & \\
\hline $\begin{array}{l}\text { Fernandes } \\
\text { Moll et al. } \\
(2018)^{48}\end{array}$ & Brazil & $\begin{array}{l}\text { Investigating the } \\
\text { perceptions and } \\
\text { expectations of family } \\
\text { members/caregivers of } \\
\text { psychiatric nursing care. }\end{array}$ & $\begin{array}{l}\mathrm{N}=10 \\
\text { Nature of relationship: } 50 \% \text { parents } \\
\mathrm{M} / \mathrm{F}: 7 / 3 \\
\text { Average age: } 58.8 \\
\text {-- } \\
\text { Patient diagnosis: } 6 \text { schizophrenia, } 3 \\
\text { depression, } 1 \text { drug abuse }\end{array}$ & $\begin{array}{l}\text { Semi- } \\
\text { structured } \\
\text { interviews }\end{array}$ & Content analysis & 8 \\
\hline $\begin{array}{l}\text { Park \& Lee } \\
(2017)^{49}\end{array}$ & $\begin{array}{l}\text { South } \\
\text { Korea }\end{array}$ & $\begin{array}{l}\text { Exploring Korean sibling } \\
\text { caregivers' experiences with } \\
\text { siblings with schizophrenia } \\
\text { that had been hospitalised } \\
\text { in an inpatient psychiatric } \\
\text { unit. }\end{array}$ & $\begin{array}{l}\mathrm{N}=8 \\
\text { Nature of relationship: } 8 \text { siblings } \\
\text { M/F: } 3 / 5 \\
\text { Age: } 20 \text { s to } 40 \mathrm{~s} \\
\text { - } \\
\text { Patient diagnosis: } 3 \text { schizophrenia }\end{array}$ & $\begin{array}{l}\text { Semi- } \\
\text { structured } \\
\text { interviews, } \\
\text { supplemented } \\
\text { by field notes } \\
\text { and memos }\end{array}$ & $\begin{array}{l}\text { Descriptive } \\
\text { Phenomenology } \\
\text { (Colaizzi's) }\end{array}$ & 8 \\
\hline $\begin{array}{l}\text { Wilkinson \& } \\
\text { McAndrew } \\
(2008)^{25}\end{array}$ & UK & $\begin{array}{l}\text { Examining carers' } \\
\text { perceptions of their level of } \\
\text { involvement in acute } \\
\text { inpatient care. }\end{array}$ & $\begin{array}{l}\mathrm{N}=4 \\
\text { Nature of relationship: } 2 \text { mothers, } 1 \text { wife, } 1 \\
\text { husband } \\
\text { M/F: } 1 / 3 \\
\text { - } \\
\text { Patient diagnosis: } 2 \text { paranoid } \\
\text { schizophrenia, } 1 \text { depression, } 1 \text { bipolar } \\
\text { disorder }\end{array}$ & $\begin{array}{l}\text { In-depth } \\
\text { interview }\end{array}$ & $\begin{array}{l}\text { Hermeneutic } \\
\text { Phenomenology } \\
\text { (Heidegger's) }\end{array}$ & 10 \\
\hline $\begin{array}{l}\text { Wood et al. } \\
(2013)^{50}\end{array}$ & UK & $\begin{array}{l}\text { Examining the extent to } \\
\text { which carers are positioned } \\
\text { as 'outsiders' in inpatient } \\
\text { settings, and how } \\
\text { 'permeable' hospitals are. }\end{array}$ & $\mathrm{N}=9$ carers (and 1 staff) & $\begin{array}{l}\text { Discussion } \\
\text { groups and } \\
\text { semi- } \\
\text { structured } \\
\text { interviews }\end{array}$ & Thematic analysis & 9 \\
\hline
\end{tabular}




\begin{tabular}{|c|c|c|c|c|c|c|}
\hline Authors & Country & Aim & Sample size \& characteristics & $\begin{array}{l}\text { Data } \\
\text { collection } \\
\text { method }\end{array}$ & Analytic approach & $\begin{array}{l}\text { CASP } \\
\text { Score } \\
\text { (max } \\
10)\end{array}$ \\
\hline $\begin{array}{l}\text { Wyder et al. } \\
(2018)^{51}\end{array}$ & Australia & $\begin{array}{l}\text { Exploring the experiences of } \\
\text { families of involuntary } \\
\text { mental health admissions. }\end{array}$ & $\begin{array}{l}\mathrm{N}=19 \\
\text { Nature of relationship: } 9 \text { mothers, } 6 \\
\text { fathers, } 3 \text { partners, } 1 \text { sibling } \\
\text { M/F: } 7 / 12 \\
- \\
\begin{array}{l}\text { Patient diagnosis: } 6 \text { schizophrenia, } 4 \\
\text { psychotic illness, } 4 \text { drug-induced } \\
\text { psychosis, } 1 \text { bipolar, } 1 \text { organic brain } \\
\text { disease }\end{array}\end{array}$ & $\begin{array}{l}\text { Semi- } \\
\text { structured } \\
\text { interviews, } \\
\text { with } 1 \\
\text { participant } \\
\text { emailing in } \\
\text { information }\end{array}$ & $\begin{array}{l}\text { "General inductive } \\
\text { approach" }\end{array}$ & 8 \\
\hline
\end{tabular}

\section{Table 2: Summary of themes}

\begin{tabular}{|ll|}
\hline Themes & References \\
\hline The emotional journey of inpatient care & $24,25,26,32,33,45,46,47,49,51$ \\
\hline Invisible experts & $24,25,26,33,47,50,51$ \\
\hline Carer concerns about quality of care for their loved one & $24,26,45,48,47,50,51$ \\
\hline Relationships \& partnership & $24,26,33,45,46,47,48,50,51$ \\
\hline
\end{tabular}

\section{Figures}




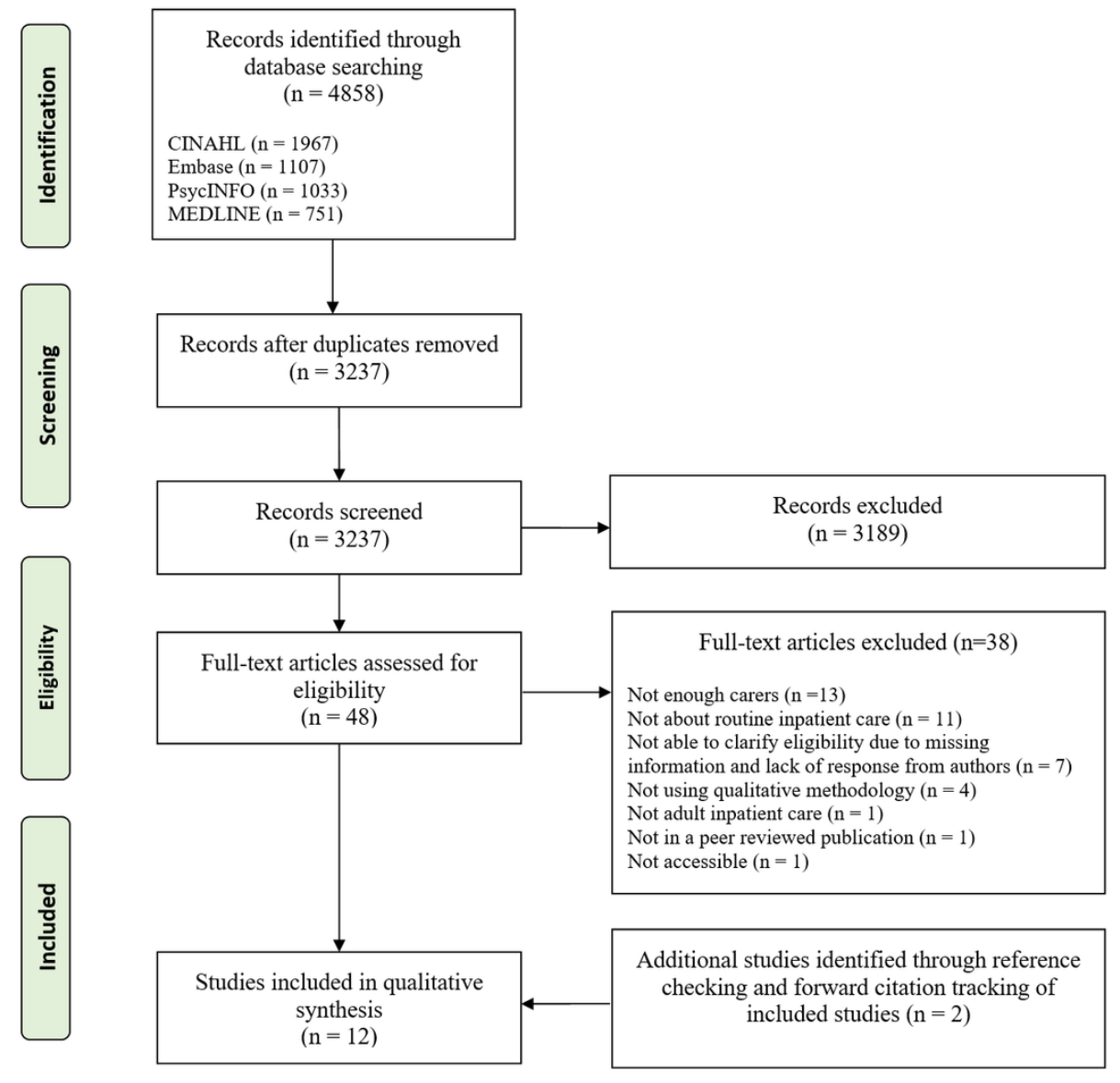

Figure 1

PRISMA Diagram 